\title{
Assessment of bioaerosols in tuberculosis high-risk areas of health care facilities in central Thailand
}

\author{
Jarmmaree Sornboot ${ }^{1,2}$, Wichai Aekplakorn ${ }^{3}$, Pongrama Ramasoota ${ }^{4}$, Surat Bualert ${ }^{5}$, \\ Somying Tumwasorn ${ }^{6}$, Wiroj Jiamjarasrangsi ${ }^{7,8, *}$
}

Abstract

Background: Long-term surveillance of airborne bioaerosols in health care facilities is required to protect the health of patients and health care workers. Feasible methods to measure airborne bioaerosol concentrations and determine associated environmental factors may help to avoid nosocomial tuberculosis (TB).

Objectives: To describe the concentrations and size of airborne bioaerosols and to identify the potential contributors to indoor airborne bioaerosols in TB high-risk areas in health care facilities.

Methods: We conducted a cross-sectional study in 7 large health care facilities located in Bangkok and nearby in central Thailand using a 6-stage Andersen cascade impactor to collect viable airborne bioaerosols that were quantified using culture techniques. Environmental parameters were determined using a tracer gas technique with an indoor air quality meter. Other potential factors were assessed using a questionnaire.

Results: The mean indoor airborne bacterial and fungal concentrations were 596.1 and 521.2 colony-forming units $(\mathrm{cfu}) / \mathrm{m}^{3}$, respectively, and the mean outdoor airborne bacterial and fungal concentrations were 496.5 and $650.1 \mathrm{cfu} / \mathrm{m}^{3}$, respectively. The majority of airborne bioaerosols were in respirable sizes. The indoor-to-outdoor ratios were 1.2 for bacteria and 0.8 for fungi. Air change rate was inversely correlated with indoor airborne bioaerosol concentrations, whereas emergency department central-type air conditioners and relative humidity were positively correlated with the indoor airborne bioaerosol concentrations $(P<0.05)$.

Conclusions: High indoor bioaerosol concentrations found in the health care facilities suggest that it is imperative to improve the indoor air quality. Improved air change rate and avoiding use of central-type air-conditioning systems may reduce bioaerosol concentrations.

Keywords: aerosols, bacteria, fungi, mycobacterium, particulate matter

*Correspondence to: Wiroj Jiamjarasrangsi, Department of Preventive and Social Medicine, Faculty of Medicine, Chulalongkorn University, Bangkok 10330, Thailand, e-mail: wiroj.j@chula.ac.th

'Health Research and Management Program, Department of Preventive and Social Medicine, Faculty of Medicine, Chulalongkorn University, Bangkok 10300, Thailand

2Department of Community Health, Sirindhorn College of Public Health, Yala 95000, Thailand

${ }^{3}$ Department of Community Medicine, Faculty of Medicine, Ramathibodi Hospital, Mahidol University, Bangkok 10400, Thailand

${ }^{4}$ Department of Social and Environmental Medicine, Faculty of Tropical Medicine, Mahidol University, Bangkok 10400, Thailand

${ }^{5}$ Department of Environmental Science, Faculty of Environment, Kasetsart University, Bangkok 10900, Thailand

${ }^{6}$ Department of Microbiology, Faculty of Medicine, Chulalongkorn University, Bangkok 10300, Thailand

${ }^{7}$ Department of Preventive and Social Medicine, Faculty of Medicine, Chulalongkorn University, Bangkok 10300, Thailand

${ }^{8}$ Department of Preventive and Social Medicine, King Chulalongkorn Memorial Hospital, Thai Red Cross Society, Bangkok 10300, Thailand 
Indoor air quality should be a matter of daily concern, because most people spend time indoors [1]. Building occupants are exposed to airborne particulate matter including bioaerosols [2]. Quality indoor air is imperative for hospitals or health care facilities, where the air is potentially contaminated with microorganisms because poor air quality can be a potential source of various nosocomial diseases. Exposure to indoor airborne bacteria and fungi may impact the health of people in affected areas [3]. Studies from Thailand $[4,5]$, Taiwan [6], Singapore [7], and Egypt [8] have shown that indoor airborne bacterial and fungal concentrations in hospitals exceeded the recommended levels of airborne microorganisms in the buildings (bacteria and fungi $\leq 500$ colony-forming units $(\mathrm{cfu}) / \mathrm{m}^{3}$ ) [9]. A study of air quality at a hospital found that wards accommodating patients at risk for tuberculosis (TB) had high bacterial and fungal counts [5]. Long-term surveillance of airborne bioaerosols in health care facilities is required to protect both patients and health care workers [10].

TB, a respiratory disease caused by Mycobacterium tuberculosis, is a major public health problem. The World Health Organization (WHO) reported that TB is one of the top 10 causes of death worldwide during 2000-2015, and Thailand has one of the highest TB burdens [11]. Currently, there are a number of studies of a method for detecting airborne M. tuberculosis and assessing the risk of TB exposure in health care facilities by using air-sampling techniques with quantitative real-time polymerase chain reaction assays [12-14]. These studies showed that the direct detection of M. tuberculosis in ambient air remains complex and the detection rate is low. Therefore, a feasible alternative to detect airborne bacterial and fungal concentrations and their associated environmental factors may help to predict the transmission of nosocomial TB in TB high-risk areas of health care facilities.

The aims of the present study were to determine the concentrations and sizes of airborne bioaerosols (bacteria and fungi) and their contributing factors in TB high-risk areas in 7 large health care facilities in central Thailand. Specifically, we sought to determine the indoor-to-outdoor $(\mathrm{I} / \mathrm{O})$ ratio of airborne bioaerosols and examine the relationship between the concentration of indoor airborne bioaerosols and environmental parameters of the areas such as air change rate, room temperature and relative humidity, type of ventilation, daily number of occupants, daily number of active TB patient(s), and daily number of coughs by TB patients not wearing a protective mask

\section{Methods}

\section{Study areas}

This cross-sectional study was conducted in 7 large health care facilities in Bangkok and nearby in central Thailand: 2 university hospitals, 1 super tertiary care hospital, 3 regional/ general hospitals, and 1 National Infectious Disease Institute. The TB high-risk areas in each health care facility targeted for this study were TB outpatient clinics, TB inpatient wards, emergency departments, and bronchoscopy units. Data were collected from January to December 2015.

\section{Ethical approval}

The present study was approved by an ethics committee at each site. For the 2 university hospitals, the institutional review board (IRB) approval numbers were 795/2014 (IRB No. 484/57 Chulalongkorn University, Faculty of Medicine) and MURA251/2015 (Faculty of Medicine Ramathibodi Hospital, Mahidol University). For the super tertiary care hospital, the IRB approval number was 001/2015 (Phra Nakhon Si Ayutthaya Hospital). For the 3 regional/general (tertiary care) hospitals, the IRB approval numbers were 035/2016 (Rajavithi Hospital), 046/2015 (Pranangklao Hospital), and 003/2015 (Saraburi Hospital). For the Thai National Infectious Disease Institute, the IRB approval number was RO18b/2015.

\section{Bioaerosol sampling}

Air was sampled from 99 indoor and 28 outdoor areas including TB clinics (18 indoor and 7 outdoor areas), TB wards (47 indoor and 7 outdoor areas), emergency departments (27 indoor and 7 outdoor areas), and bronchoscopy units ( 7 indoor and 7 outdoor areas). We collected 6 air samples for each area. A total of 1,524 samples (1,188 indoor and 336 outdoor) were collected. Equal numbers of blank samples were also collected from the same areas. Air samples were collected using a sixstage Andersen cascade impactor for viable aerosols (Thermo Scientific) at a flow rate of $28.3 \mathrm{~L} / \mathrm{min}$ [15] and a sampling time of $10 \mathrm{~min}$ to determine the bioaerosol concentrations and their size distribution. The aerodynamic diameter ranges for each stage in the Andersen cascade impactor were $>7.0 \mu \mathrm{m}$ (stage 1), 4.7-7.0 $\mu \mathrm{m}$ (stage 2), 3.3-4.7 $\mu \mathrm{m}$ (stage 3), 2.1-3.3 $\mu \mathrm{m}$ (stage 4), 
1.1-2.1 $\mu \mathrm{m}$ (stage 5), and 0.65-1.1 $\mu \mathrm{m}$ (stage 6). Air samplers were disinfected with $70 \%$ ethanol before collecting the samples, and air-sampling devices were placed within $1 \mathrm{~m}$ of the patients and $1.5 \mathrm{~m}$ above the floor to represent a human breathing zone. The outdoor air samples were collected on the same day as the indoor samples. Tryptic soy agar (incubation at $37^{\circ} \mathrm{C}$ for 2 days) was used to culture airborne bacteria. Sabouraud dextrose agar (incubation at $25^{\circ} \mathrm{C}$ for 5 days) was used to culture airborne fungi [16]. The concentrations of microorganisms are expressed as $\mathrm{cfu} / \mathrm{m}^{3}$ and calculated as follows: the concentrations of microorganisms of each Andersen impactor stage $\left(\mathrm{cfu} / \mathrm{m}^{3}\right)=\left(\mathrm{cfu}\right.$ at the stage $\left.\times 10^{3}\right) /($ sampling flow rate $(\mathrm{L} / \mathrm{min}) \times($ sampling time $(\mathrm{min}))[17]$.

\section{Environmental parameters and other potential contributors}

Environmental parameters of interest in this study were air change rate $\left(\mathrm{h}^{-1}\right)$, temperature $\left({ }^{\circ} \mathrm{C}\right)$, and relative humidity $(\%)$. Air change rate was measured using a standard method to determine air change in a single zone by means of a tracer gas dilution [9], and temperature and relative humidity were measured using an AQ 200 Indoor Air Quality Meter (Kimo Instruments). Information about other potential contributing factors, such as daily number of patient(s) with active TB in each area, daily number of occupants in each area and department, and type of ventilation system, was obtained from the TB health care workers working in each area. The daily number of coughs by TB patient(s) not wearing a protective mask in each area was obtained from a TB patient interview and by direct observation by one of the authors during the $8 \mathrm{~h}$ of air sample collection per day. In addition, information about the presence of TB infection control measures was also collected using a set of structured questionnaires modified from those suggested by the WHO [18]; this questionnaire assessed infection control policy and management (11 items), administrative control (15 items), environmental control (2 items), and personal protection ( 2 items). The result was then summarized as the nosocomial TB prevention score with a total possible score of 30 , and a score of 0-10 was considered as low, 11-20 moderate, and 21-30 high.

\section{Statistical analysis}

In describing continuous variables (airborne bioaerosol concentration, air change rate, temperature and relative humidity,
TB infection control score, daily number of active TB patients in each area, daily number of coughs by TB patient(s) not wearing a protective mask in each area, and daily number of occupants in each area), the mean and standard deviation (SD) or median and 25th and 75th percentiles or interquartile range (IQR) are used for variables with normal or skewed distributions, respectively. Categorical variables (types of department and ventilation system) are presented as frequency and percentage. An unpaired $t$ test was used to compare the indoor and outdoor levels of airborne bacteria and fungi. $P<0.05$ was considered significant.

The association between indoor airborne bioaerosol concentration and potential contributing factors (potential environmental attributors and ventilation systems) was initially examined by linear regression. Subsequently, multiple linear regression was conducted. Backward stepwise selection was used in the statistical modeling by including variables with $P<0.25$ in the model and those with $P<0.10$ were retained in the final model. $P<0.05$ was considered significant in tests of statistical inference. We used data transformation for skewed variables before importing them into the model. The model from a log-transformed regression showed that the value of unstandardized coefficients, $B$ and $P$, corresponded to final model. The data were analyzed using IBM SPSS Statistics for Windows, version 22.0.

\section{Results}

\section{General characteristics of TB high-risk areas}

In TB high-risk areas, the median air change rate was $6.2 \mathrm{~h}^{-1}$, temperature was $27.9^{\circ} \mathrm{C}$, and relative humidity was $62.2 \%$, while the daily number of occupants in each area was 10.0, daily number of patient(s) with active TB in each area was 1.0, and daily number of coughs by TB patient(s) not wearing a protective mask in each area was 0.0 . The TB infection control scores for most areas were high (21-30 of the total score of 30). The ventilation systems used in the areas were mostly splittype (44\%) and central-type air conditioners (48\%; Table 1).

\section{Airborne bacterial and fungal concentrations}

The mean indoor (all areas) airborne bacterial and fungal concentrations were 596.1 and $521.2 \mathrm{cfu} / \mathrm{m}^{3}$, respectively, and the 
Table 1. Indoor bacterial and fungal concentrations in TB high-risk areas based on environmental parameters and other potential contributors

\begin{tabular}{|c|c|c|c|c|c|}
\hline $\begin{array}{l}\text { Data for TB high-risk areas } \\
\text { Median (IQR), unless } \\
\text { indicated otherwise }\end{array}$ & $\begin{array}{l}\text { Emergency } \\
\text { department } \\
(n=27)\end{array}$ & TB ward $(n=47)$ & $\begin{array}{c}\text { Bronchoscopy } \\
\text { unit } \\
(n=7)\end{array}$ & $\begin{array}{l}\text { TB clinic } \\
(\mathrm{n}=18)\end{array}$ & $\begin{array}{c}\text { All areas } \\
(n=99)\end{array}$ \\
\hline Air change rate $\left(\mathrm{h}^{-1}\right)$ & $6.0(5.9-6.2)$ & $6.7(6.1-7.3)$ & $7.0(5.2-7.1)$ & $6.3(5.2-7.0)$ & $6.2(6.0-7.1)$ \\
\hline Temperature $\left({ }^{\circ} \mathrm{C}\right)$ & $25.6(25.1-27.1)$ & $31.5(29.1-32.0)$ & $24.6(24.2-25.7)$ & $28.3(26.3-30.7)$ & $27.9(25.3-31.5)$ \\
\hline Relative humidity (\%) & $61.7(60.0-63.7)$ & $66.7(57.8-70.1)$ & $57.2(53.8-66.3)$ & $68.2(58.2-70.6)$ & $62.2(57.8-70.0)$ \\
\hline TB infection control score ${ }^{\dagger}$ & $24.0(21.0-28.0)$ & $26.0(22.0-28.0)$ & $21.0(14.0-25.0)$ & $27.0(23.8-28.0)$ & $26.0(22.0-28.0)$ \\
\hline Good level, frequency (\%) & $23.0(85.2)$ & $37.0(78.7)$ & $4.0(57.1)$ & $16.0(88.9)$ & $80.0(80.8)$ \\
\hline Moderate level, frequency (\%) & $4.0(14.8)$ & $10.0(21.3)$ & $3.0(42.9)$ & $2.0(11.1)$ & $19.0(19.2)$ \\
\hline Daily number of occupants in each area & $35.0(15.0-60.0)$ & $7.0(5.0-10.0)$ & $6.0(5.0-15.0)$ & $20.0(6.8-69.3)$ & $10.0(5.0-30.0)$ \\
\hline Daily number of active TB patient(s) in each area & - & $1.0(1.0-1.0)$ & $1.0(0.0-1.0)$ & $2.0(1.0-7.0)$ & $1.0(0.0-1.0)$ \\
\hline $\begin{array}{l}\text { Daily number of coughs by TB patient(s) not } \\
\text { wearing a protective mask in each area }\end{array}$ & & $1.0(0.0-1.0)$ & $3.0(1.0-3.0)$ & - & $0.0(0.0-1.0)$ \\
\hline \multicolumn{6}{|l|}{ Ventilation system } \\
\hline Natural ventilation, frequency (\%) & $2.0(7.4)$ & $37.0(78.7)$ & - & $8.0(44.4)$ & $47.0(47.5)$ \\
\hline Central-type air conditioner, frequency (\%) & $12.0(44.4)$ & - & - & $7.0(38.9)$ & $19.0(19.2)$ \\
\hline Split-type air conditioner, frequency (\%) & $13.0(48.2)$ & $10.0(21.3)$ & $7.0(100.0)$ & $3.0(16.7)$ & $33.0(33.3)$ \\
\hline Indoor airborne bacteria $\left(\mathrm{cfu} / \mathrm{m}^{3}\right)^{\ddagger}$ & $691.0 \pm 79.61$ & $533.8 \pm 132.50$ & $567.9 \pm 208.55$ & $627.2 \pm 124.60$ & $596.1 \pm 140.90$ \\
\hline Indoor airborne fungi $\left(\mathrm{cfu} / \mathrm{m}^{3}\right)^{\ddagger}$ & $618.4 \pm 108.03$ & $464.7 \pm 130.11$ & $478.1 \pm 178.01$ & $539.7 \pm 129.59$ & $521.2 \pm 142.20$ \\
\hline
\end{tabular}

$\mathrm{IQR}$, interquartile range; $\mathrm{SD}$, standard deviation; $\mathrm{TB}$, tuberculosis

${ }^{+}$Good level = score 21-30 score; moderate level = score 11-20; poor level = score 0-10

${ }^{\ddagger} \mathrm{cfu} / \mathrm{m} 3$ : colony forming unit per cubic meter, mean $\pm \mathrm{SD}$

mean outdoor airborne bacterial and fungal concentrations were 496.5 and $650.1 \mathrm{cfu} / \mathrm{m}^{3}$, respectively. The emergency department had the highest mean indoor and outdoor concentrations of airborne bacteria and fungi; the concentrations were higher than other areas studied (indoors $691.0 \mathrm{cfu} / \mathrm{m}^{3}$ and 618.4 $\mathrm{cfu} / \mathrm{m}^{3}$ for bacteria and fungi, and outdoors $523.5 \mathrm{cfu} / \mathrm{m}^{3}$ and $721.4 \mathrm{cfu} / \mathrm{m}^{3}$, respectively). The TB wards had the lowest mean concentrations of airborne bacteria and fungi (indoors 533.8 $\mathrm{cfu} / \mathrm{m}^{3}$ and $464.7 \mathrm{cfu} / \mathrm{m}^{3}$, and outdoors $461.5 \mathrm{cfu} / \mathrm{m}^{3}$ and 583.0 $\mathrm{cfu} / \mathrm{m}^{3}$, respectively) as shown in Figure 1 .

The indoor airborne bacterial concentrations were significantly higher than the outdoor airborne bacterial concentrations (I/O = 1.2, $P<0.05$ ), while the indoor fungal concentrations were significantly lower than the outdoor airborne fungal concentrations $(\mathrm{I} / \mathrm{O}=0.8, P<0.001)$. According to the criteria recommended by the American Conference of Governmental Industrial Hygienists (ACGIH), the total levels of the airborne bacterial and fungal levels should be $\leq 500 \mathrm{cfu} / \mathrm{m}^{3}$ [9]. In the present study, the airborne bacteria exceeded the recommended levels in 67/99 areas (68\%) and airborne fungi exceeded the recommended levels in 50/99 areas $(50.5 \%$; Figure 1).

The size distributions of airborne bacteria and fungi peaked at stage 3-4 (2.1-4.7 $\mu \mathrm{m})$, and their median concentrations were at 245.6 and $219.1 \mathrm{cfu} / \mathrm{m}^{3}$, respectively. The median concentrations of airborne bacteria and fungi for all size distributions were highest in the emergency departments and lowest in bronchoscopy units as shown in Figure 2.

\section{Potential contributing factors for airborne bacterial and fungal concentrations}

The linear regression found that the potential contributing factors for indoor airborne bioaerosol concentrations were environmental parameters and other potential contributors, including ventilation systems as summarized in Table 2 . The concentration of indoor airborne bioaerosols correlated positively with relative humidity, daily number of occupants in each area, types of department (e.g., emergency department), and ventilation system (e.g., central-type air conditioner). By contrast, the concentration of indoor airborne bioaerosols was negatively correlated with air change rate $(P<0.05)$. Daily number of coughs by TB patient(s) not wearing a protective mask in each area was positively correlated with indoor airborne bacterial concentrations $(P<0.05)$. However, the multiple linear regression analysis showed that the concentration of indoor airborne bioaerosols was positively correlated only with relative humidity, types of department (e.g., emergency department), and ventilation system (e.g., central-type air conditioner) and was negatively correlated with air change rate $(P<0.05$; Table 3). 


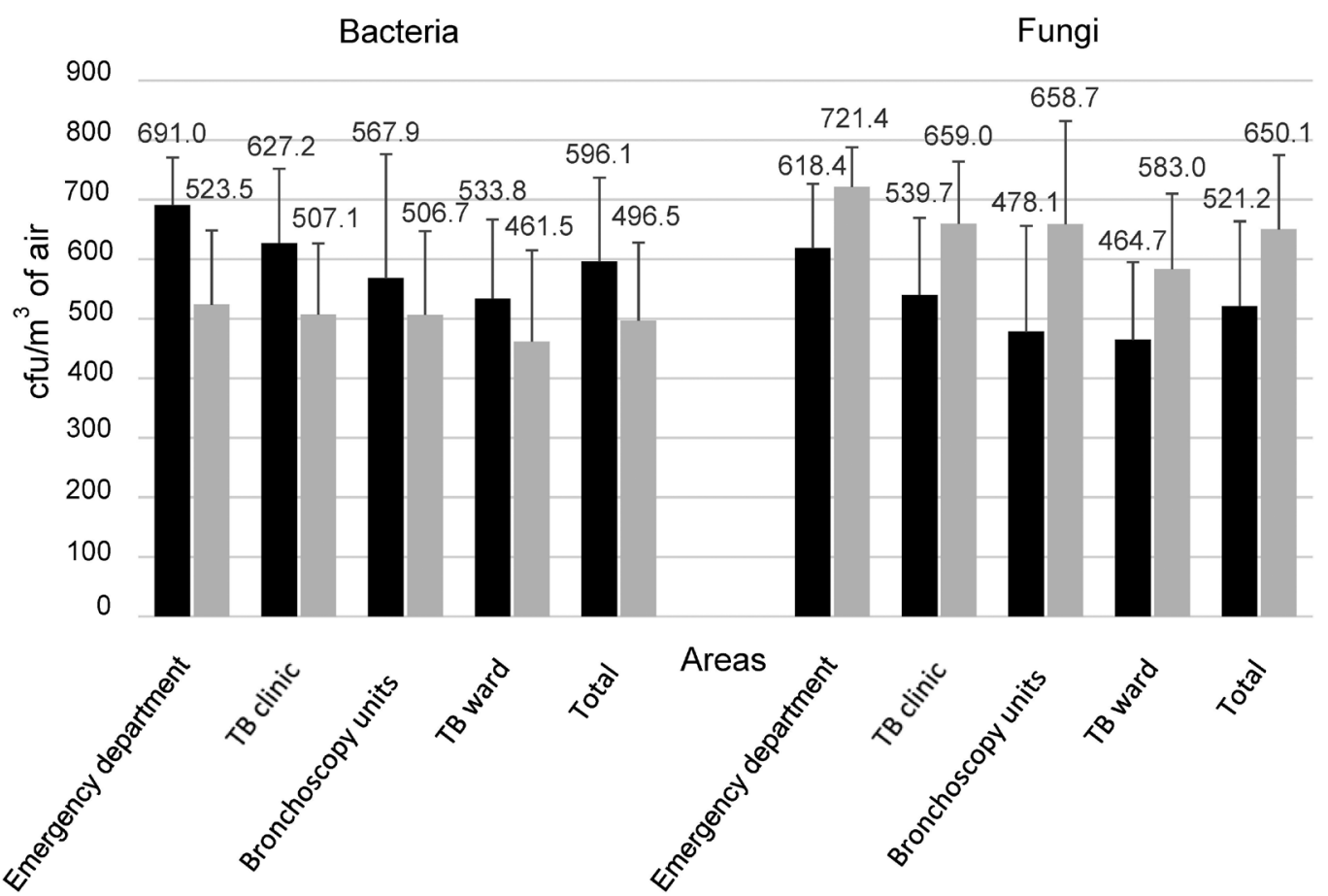

Figure 1. Concentrations of airborne bacteria and fungi, indoors (black bars) and outdoors (gray bars), in the emergency department, TB clinic, bronchoscopy unit, TB ward, and all areas (total). Error bars indicate SD from the mean (indicated above bars).

$\mathrm{SD}$, standard deviation; TB, tuberculosis

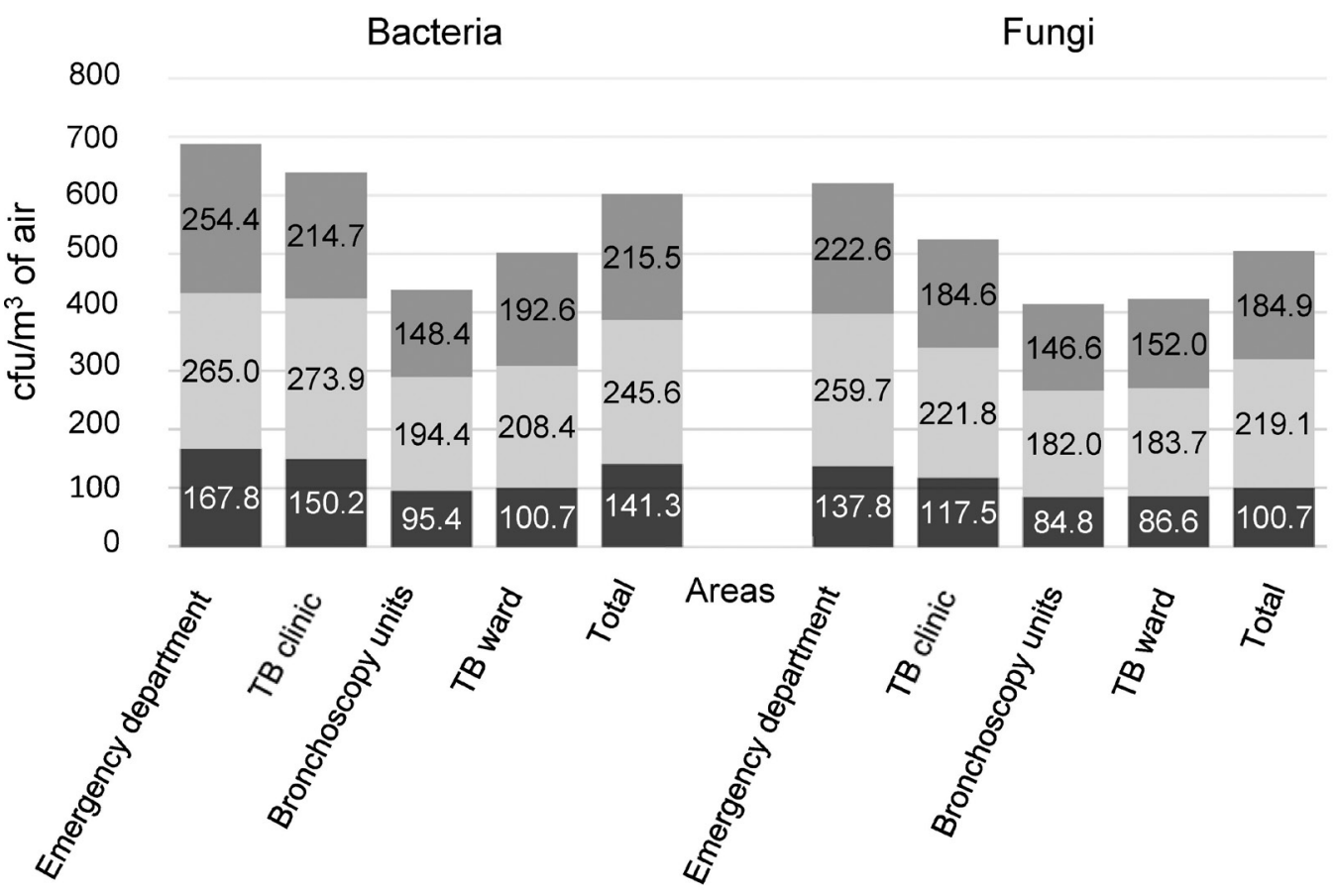



Figure 2. Size distributions of indoor airborne bacteria and fungi in emergency department, TB clinic, bronchoscopy unit, TB ward, and all areas (total). Median concentration ( $\mathrm{cfu} / \mathrm{m}^{3}$ ) at each Andersen impactor stage is indicated within the stacked bars. The stages are coded according to the key at the bottom of the Figure.

TB, tuberculosis 
Table 2. Comparison of factors and indoor airborne bioaerosol concentration using linear regression

\begin{tabular}{|c|c|c|c|c|c|c|}
\hline \multirow[t]{2}{*}{ Factor } & \multicolumn{3}{|c|}{ Bacteria $\left(\mathrm{cfu} / \mathrm{m}^{3}\right)^{\dagger}$} & \multicolumn{3}{|c|}{ Fungi $\left(\mathrm{cfu} / \mathrm{m}^{3}\right)^{\dagger}$} \\
\hline & $\mathbf{B}^{+}$ & 95\% Cl (lower, upper) & $P$ & $\mathbf{B}^{\mathbf{a}}$ & 95\% Cl (lower, upper) & $\boldsymbol{P}$ \\
\hline Air change rate $\left(\mathrm{h}^{-1}\right)$ & -71.30 & $-87.54,-55.06$ & $<0.001^{* * *}$ & -71.64 & $-88.09,-55.19$ & $<0.001^{* * *}$ \\
\hline Temperature $\left({ }^{\circ} \mathrm{C}\right)$ & -5.54 & $-14.77,3.69$ & 0.24 & -4.36 & $-13.70,4.99$ & 0.36 \\
\hline Relative humidity (\%) & 6.66 & $2.20,11.12$ & $0.004^{* *}$ & 6.07 & $1.53,10.61$ & $0.009^{* *}$ \\
\hline TB infection control score & -3.39 & $-10.48,3.07$ & 0.35 & -4.77 & $-11.89,2.36$ & 0.19 \\
\hline $\begin{array}{l}\text { Daily number of patients with active } \\
\text { TB (in each area) }\end{array}$ & -8.69 & $-19.24,1.85$ & 0.11 & -9.03 & $-19.66,1.61$ & 0.095 \\
\hline Daily number of occupants in each area & 1.81 & $0.75,2.87$ & $0.001^{* *}$ & 1.82 & $0.75,2.89$ & $0.001^{* *}$ \\
\hline $\begin{array}{l}\text { Daily number of coughs by TB patients } \\
\text { (not wearing a protective mask) } \\
\text { Department }^{\ddagger}\end{array}$ & 14.81 & $2.14,27.47$ & $0.022^{*}$ & 10.40 & $-2.56,23.37$ & 0.14 \\
\hline Emergency department & 130.49 & $72.77,188.22$ & $<0.001^{* * *}$ & 133.59 & $75.50,191.67$ & $<0.001^{* * *}$ \\
\hline TB clinic and bronchoscopy unit & 19.42 & $-45.48,84.33$ & 0.55 & 1.68 & $-63.95,67.30$ & 0.96 \\
\hline Ventilation system ${ }^{\S}$ & & & & & & \\
\hline Central-type air conditioner & 166.08 & $102.63,229.53$ & $<0.001^{* * *}$ & 164.41 & $100.03,228.78$ & $<0.001^{* * *}$ \\
\hline Split-type air conditioner & -46.27 & $-105.46,12.93$ & 0.12 & -53.67 & $-113.17,5.84$ & 0.077 \\
\hline
\end{tabular}

${ }^{\text {T}}$ The mean indoor airborne bacteria and fungi ( $\mathrm{cfu} / \mathrm{m}^{3}=$ colony forming unit per cubic meter)

"Emergency department (TB clinic and bronchoscopy unit, and TB ward =0, Emergency department $=1$ ), TB clinic and bronchoscopy unit (Emergency department and TB ward $=0$, TB clinic and bronchoscopy unit $=1$ )

${ }^{\S}$ Central type air conditioner (natural ventilation and split type air conditioner $=0$, central type air conditioner $=1$ ), Split type air conditioner (natural ventilation and central type air conditioner $=0$, split type air conditioner $=1$ )

${ }^{*} P<0.05$

$* * P<0.01$

***P $<0.001$

Table 3. Comparison of factors and indoor airborne bioaerosol concentration using multiple linear regression

\begin{tabular}{|c|c|c|c|c|c|c|}
\hline \multirow[t]{2}{*}{ Factors } & \multicolumn{3}{|c|}{ Bacteria $\left(\mathbf{c f u} / \mathrm{m}^{3}\right)^{+}$} & \multicolumn{3}{|c|}{ Fungi $\left(\mathrm{cfu} / \mathrm{m}^{3}\right)^{+}$} \\
\hline & $\mathbf{B}^{+}$ & 95\% Cl (lower, upper) & $P$ & $\mathbf{B}^{+}$ & 95\% Cl (lower, upper) & $P$ \\
\hline Air change rate $\left(\mathrm{h}^{-1}\right)$ & -50.48 & $-64.99,-35.97$ & $<0.001^{* * *}$ & -51.57 & $-66.66,-36.48$ & $<0.001^{* * *}$ \\
\hline Relative humidity (\%) & 7.27 & $4.25,10.29$ & $<0.001^{* * *}$ & 6.59 & $3.44,9.73$ & $<0.001^{* * *}$ \\
\hline Emergency department ${ }^{\ddagger}$ & 65.05 & $21.99,108.12$ & $0.003^{* *}$ & 68.37 & $23.58,113.15$ & $0.003^{* *}$ \\
\hline Central-type air conditioner ${ }^{\S}$ & 113.90 & $63.60,164.19$ & $0.001^{* *}$ & 107.38 & $55.08,159.68$ & $<0.001^{* * *}$ \\
\hline Constant & 429.84 & $191.73,667.96$ & 0.001 & 405.80 & $158.18,653.42$ & 0.002 \\
\hline
\end{tabular}

${ }^{\top}$ The mean indoor airborne bacteria and fungi ( $\mathrm{cfu} / \mathrm{m}^{3}=$ colony forming unit per cubic meter)

EEmergency department (TB clinic and bronchoscopy unit, and TB ward =0, Emergency department $=1$ ), TB clinic and bronchoscopy unit (Emergency department and TB ward $=0$, TB clinic and bronchoscopy unit $=1$ )

${ }^{\S}$ Central type air conditioner (natural ventilation and split type air conditioner $=0$, central type air conditioner $=1$ ), split type air conditioner (natural ventilation and central type air conditioner $=0$, split type air conditioner $=1$ )

Model bacteria $\left(\mathrm{cfu} / \mathrm{m}^{3}\right) \mathrm{r}^{2}=0.636$, model fungi $\left(\mathrm{cfu} / \mathrm{m}^{3}\right) \mathrm{r}^{2}=0.614$

${ }^{*} P<0.05$

$* * P<0.01$

\section{Discussion}

\section{General characteristics of TB high-risk areas}

The present study found that the mean $\pm \mathrm{SD}$ of the concentration of indoor airborne bacteria $\left(596.1 \pm 140.90 \mathrm{cfu} / \mathrm{m}^{3}\right)$ and fungi $\left(521.2 \pm 142.20 \mathrm{cfu} / \mathrm{m}^{3}\right)$ exceeded the levels recommended by the ACGIH $\left(\leq 500 \mathrm{cfu} / \mathrm{m}^{3}\right)[9]$ by more than half in the areas studied (bacteria $67.7 \%$ and fungi $50.5 \%$ ). This finding is consistent with findings from a survey by Chaivisit et al. who assessed the concentrations of airborne bacteria and fungi in a medical intensive care unit in a tertiary care hospital in Thailand in 2016, in which the indoor airborne bacterial 
concentration was $515.1 \pm 246.75$ and the indoor airborne fungal concentration was $531.4 \pm 337.65 \mathrm{cfu} / \mathrm{m}^{3}$ [4]. However, 2 other surveys conducted in other hospitals in Thailand found comparable levels of indoor airborne bacteria, but much lower levels for indoor airborne fungi. In 2014, Luksamijarulkul et al. studied the indoor airborne bacterial and fungal concentrations in the waiting areas of 4 government hospitals in Bangkok and found that the bacterial levels were from $355.7 \pm 86.8$ to $500.8 \pm 64.2 \mathrm{cfu} / \mathrm{m}^{3}$ and fungal levels were from $222.0 \pm 74.1$ to $258.3 \pm 110.2 \mathrm{cfu} / \mathrm{m}^{3}$. However, the levels in laboratories in these hospitals were found to be substantially lower; the bacterial levels were from $146.7 \pm 127.0$ to $304.4 \pm 264.2 \mathrm{cfu} / \mathrm{m}^{3}$ and fungal levels were from $101.6 \pm 71.6$ to $175.3 \pm 101.2$ $\mathrm{cfu} / \mathrm{m}^{3}$ [19]. Another study conducted in 2014 in a hospital in Bangkok found that in the outpatient department the airborne bacterial level was $575 \pm 253 \mathrm{cfu} / \mathrm{m}^{3}$ and fungal level was $262 \pm 218 \mathrm{cfu} / \mathrm{m}^{3}$, while in a male medical ward the airborne bacterial level was $428 \pm 295 \mathrm{cfu} / \mathrm{m}^{3}$ and fungal level was $134 \pm 122 \mathrm{cfu} / \mathrm{m}^{3}$; in a female medical ward the airborne bacterial level was $331 \pm 172 \mathrm{cfu} / \mathrm{m}^{3}$ and fungal level was $162 \pm 66 \mathrm{cfu} / \mathrm{m}^{3}$; and in the emergency room the airborne bacterial level was $216 \pm 66 \mathrm{cfu} / \mathrm{m}^{3}$ and fungal level was $132 \pm 117 \mathrm{cfu} / \mathrm{m}^{3}$ [20].

The findings from the present study are consistent with a study conducted in Singapore, which found that the airborne bacterial levels were high in a hospital lobby $\left(445-890 \mathrm{cfu} / \mathrm{m}^{3}\right)$ and pharmacy (201-827 cfu/ $\mathrm{m}^{3}$ ) [7], and a study conducted in a hospital in Taiwan found that the level of airborne fungi was $699.3 \mathrm{cfu} / \mathrm{m}^{3}$ in the morning and was $626.2 \mathrm{cfu} / \mathrm{m}^{3}$ in the afternoon [6]. A study conducted in Egypt found that bacterial levels were $728.3 \pm 673.2 \mathrm{cfu} / \mathrm{m}^{3}$ in an operating theater and $1,622.2 \pm 663.1 \mathrm{cfu} / \mathrm{m}^{3}$ in the admission department of a governmental hospital and $512 \pm 425.3 \mathrm{cfu} / \mathrm{m}^{3}$ in the intensive care unit and $1,126.5 \pm 763.1 \mathrm{cfu} / \mathrm{m}^{3}$ in the admission department of a private hospital [8].

We found that the size distributions of indoor airborne bioaerosols (bacteria and fungi) peaked at stage 3-4 (2.1-4.7 $\mu \mathrm{m})$ as consistent with previous findings. In a university hospital in Thailand, the bacterial aerosol sizes in a medical intensive care unit and fungal aerosol sizes in a surgical intensive care unit peaked at 2.1-3.3 $\mu \mathrm{m}$ [4], whereas a study in Taiwan reported that the indoor fungal aerosol sizes peaked at $0.65-2.5 \mu \mathrm{m}[6]$.

Contamination with airborne bacteria and fungi can be monitored using the $\mathrm{I} / \mathrm{O}$ ratio [21]. We found that $\mathrm{I} / \mathrm{O}$ ratios were consistent with those found by other studies. The I/O ratios for airborne bacteria and fungi exceeded 1 $(\mathrm{I} / \mathrm{O}>1)$ in the admission departments of government hospitals in Egypt [8]. A study of airborne bacteria and fungi conducted in Korea found that $\mathrm{I} / \mathrm{O}>1$ in public buildings, whereas in a number of hospitals the ratios were $<1.0$ [21]. A study conducted in a tertiary care hospital in Thailand found that the $\mathrm{I} / \mathrm{O}$ ratio of airborne bacteria was highest $(>1)$ in a medical intensive care unit [4]. We found that indoor $(P<0.05)$ and outdoor $(P<0.001)$ airborne bacterial and fungal levels were significantly different. Because humans can generate approximately $3.7 \times 10^{7}$ bacterial genome copies/person/hour, bacterial levels in indoor air may be related to the activity and the density of the occupants, rather than the contamination from the indoor air $[2,7]$. A study of indoor fungi conducted in a university hospital in Iran showed that the indoor levels were affected by the concentration of outdoor fungi [22]. This suggests that the contributions to indoor airborne fungal concentrations are from conditions outdoors $[2,21]$. If fungi are found in the building, possible sources are water-damaged sites [2].

\section{Factors related to indoor bioaerosol concentration}

Our finding that low air change rates $\left(\mathrm{h}^{-1}\right)$ were associated with high levels of airborne bioaerosols supports findings by previous studies that ventilation and air-conditioning systems are a source of airborne microorganisms [2] and the detection and microbial spread of pathogenic microorganisms such as airborne TB in a hospital may be related to air change rates or ventilation [12]. We found that more than half (55.5\%) of the study areas had inadequate ventilation (data not shown). In these areas, air conditioners were used $24 \mathrm{~h}$ per day, 7 days per week, and most of had $>10$ years lifetime, which may reduce their efficiency resulting in inadequate ventilation. Inadequate ventilation, poor temperature control, and high relative humidity can promote bacterial and fungal growth and spread [7, 23].

In emergency departments, the daily occupancy in each area and air change rates were positively associated $(P<0.01)$ with indoor airborne bacterial and fungal levels, and the daily number of coughs by TB patient(s) not wearing a protective mask in each area was positively correlated $(P=0.02)$ with indoor airborne bacterial levels. In a university hospital in Iran, the emergency department had the highest airborne levels of bacteria [22]. Similarly, the emergency departments of Portuguese hospitals [24] and a hospital in Thailand [5] had high airborne levels of both bacteria and fungi.

The ventilation in some emergency departments was extremely inadequate [25]. Such inadequacy can affect the health of patients and medical staff, because emergency departments support a variety of activities and high volumes of patients and medical staff. Indoor bioaerosols are associated with human-related bacteria. Many types of bacteria humans carry in their respiratory tract and saliva are released into the environment when people cough, sneeze, and speak. Therefore, if a patient does not use a mask and 
coughs, indoor airborne bacterial levels will increase [2, 7]. However, this factor is not associated with indoor airborne fungal levels, because the main source of fungi is from outdoors $[2,4,21]$.

Our finding that temperature was unrelated to indoor bioaerosol concentration is consistent with previous findings from Thailand [4] and Singapore [7]. An association may be lacking, because each microorganism has a different optimal temperature range for growth, which affects its airborne bioaerosol level. Nor did the number of patient(s) with active $\mathrm{TB}$ in each area per day correlate with indoor bioaerosol levels, possibly because this number was negligible compared with the number of all occupants of the areas. Therefore, any additive effect on the airborne levels of bioaerosols may be miniscule. The TB infection control score was not associated with the indoor bioaerosol level, because the study areas have mostly implemented TB infection controls. As a result of these controls, the statistical power of areas without strong controls was limited and we therefore cannot determine the impact of TB patients on the total indoor bioaerosol levels.

\section{Conclusion}

In TB high-risk areas of health care facilities, the largest proportion of indoor airborne bioaerosol sizes were in the respirable fraction; the source of airborne bacteria was from indoors while that of fungi was from outdoors. More than half of the areas had indoor airborne bacterial and fungal levels that exceeded the recommendations of the ACGIH [9]. Therefore, control measures for indoor airborne bacterial and fungal levels in the hospitals are warranted. Potential contributors to the indoor airborne levels are low air change rates, central-type air-conditioning systems, and high relative humidity.

Author contributions. All the authors contributed substantially to the study conception and design, acquisition of data, and its analysis. JS, WA, PR, and WJ drafted the manuscript, and JS, SB, ST, and WJ critically revised it. All the authors approved the final version submitted for publication and take responsibility for statements made in the published article.

Acknowledgments. The authors thank Ajcharaporn Sawatpanich for his technical assistance. This work was supported by the Ratchadapiseksompotch Fund, Faculty of Medicine, Chulalongkorn University (RA 2015/015), the 90th Anniversary of Chulalongkorn University Fund (grant No. 16, 2/2014), and the FY2016 Thesis Grant for Doctoral Degree Student of the National Research Council of Thailand (NRCT; grant No. $1 / 19,2016)$.

Conflict of interest statement. The authors have each completed and submitted an International Committee of Medical Journal Editors Form for Disclosure of Potential Conflicts of Interest. None of the authors have any potential conflict of interest to disclose.

\section{References}

[1] Klepeis NE, Nelson WC, Ott WR, Robinson JP, Tsang AM, Switzer P, et al. The National Human Activity Pattern Survey (NHAPS): a resource for assessing exposure to environmental pollutants. J Expo Anal Environ Epidemiol. 2001; 11:231-52.

[2] Prussin AJ 2nd, Marr LC. Sources of airborne microorganisms in the built environment. Microbiome. 2015; 3:78. doi: 10.1186/s40168015-0144-z

[3] Kim K-H, Kabir E, Jahan SA. Airborne bioaerosols and their impact on human health. J Environ Sci. 2018; 67:23-35.

[4] Chaivisit P, Suksaroj T, Romyen D, Choosong T. Bioaerosols assessment in the intensive care unit of a tertiary care hospital. Songkla Med J. 2016; 34:11-25.

[5] Luksamijarulkul P, Supapvanit C, Loosereewanich P, Aiumlaor P. Risk assessment towards tuberculosis among hospital personnel: administrative control, risk exposure, use of protective barriers and microbial air quality. Southeast Asian J Trop Med Public Health. 2004; 35:1005-11.

[6] Liao C-M, Luo W-C. Use of temporal/seasonal- and size-dependent bioaerosol data to characterize the contribution of outdoor fungi to residential exposures. Sci Total Environ. 2005; 347:78-97.

[7] Obbard JP, Fang LS. Airborne concentrations of bacteria in a hospital environment in Singapore. Water Air Soil Pollut. 2003; 144:333-41.

[8] Osman ME, Ibrahim HY, Yousef FA, Abo Elnasr AA, Saeed Y, Abdel Hameed AA. A study on microbiological contamination on air quality in hospitals in Egypt. Indoor Built Environ. 2018; 27:963-8.

[9] American Conference of Governmental Industrial Hygienists (ACGIH). Guidelines for the assessment of bioaerosols in the indoor environment. Cincinnati: ACGIH; 1989. p. 301.

[10] Solomon FB, Wadilo FW, Arota AA, Abraham YL. Antibiotic resistant airborne bacteria and their multidrug resistance pattern at University teaching referral Hospital in South Ethiopia. Ann Clin Microbiol Antimicrob. 2017; 16:29. doi:10.1186/s12941-017-0204-2.

[11] World Health Organization. Global tuberculosis report 2016. Geneva: WHO; 2016. p. 1, 13-4.

[12] Chen P-S, Li C-S. Concentration profiles of airborne Mycobacterium tuberculosis in a hospital. Aerosol Sci Technol. 2008; 42:194-200.

[13] Hubad B, Lapanje A. Inadequate hospital ventilation system increases the risk of nosocomial Mycobacterium tuberculosis. J Hosp Infect. 2012; 80:88-91

[14] Matuka O, Singh TS, Bryce E, Yassi A, Kgasha O, Zungu M, et al. Pilot study to detect airborne Mycobacterium tuberculosis exposure in a South African public healthcare facility outpatient clinic. J Hosp Infect. 2015; 89:192-6. 
[15] National Institute for Occupational Safety and Health (NIOSH). NIOSH Manual of Analytical Methods (NMAM). 4th ed. Aerobic bacteria by GC-FAME. Method 0801, Issue 1: 15 January 1998. Cincinnati: NIOSH; 1998. p. 1-4.

[16] Kyte L, Kleyn J, Scoggins H, Bridgen M. Plants from test tubes: an introduction to micropropagation. 4 th ed. London: Timber Press; 2013.

[17] Fang Z, Ouyang Z, Zheng H, Wang X, Hu L. Culturable airborne bacteria in outdoor environments in Beijing, China. Microb Ecol. 2007; 54:487-96.

[18] Tuberculosis Coalition for Technical Assistance (TBCTA). Implementing the WHO policy on TB infection control in health-care facilities, congregate settings and households. Washington, DC: TB CTA, The Global Health Bureau, Office of Health, Infectious Disease and Nutrition (HIDN), United States Agency for International Development (USAID); 2009.

[19] Luksamijarulkul P, Kiennukul N, Vatthanasomboon P. Laboratory facility design and microbial indoor air quality in selected hospital laboratories. Southeast Asian J Trop Med Public Health. 2014; 45:746-55.
[20] Luksamijarulkul P, Aiempradit N, Vatanasomboon P. Microbial contamination on used surgical masks among hospital personnel and microbial air quality in their working wards: a hospital in Bangkok. Oman Med J. 2014; 29:346-50.

[21] Kim KY, Kim CN. Airborne microbiological characteristics in public buildings of Korea. Build Environ. 2007; 42:2188-96.

[22] Goudarzi G, Soleimani Z, Sadeghinejad B, Alighardashi M, Latifi SM, Moradi M. Visiting hours impact on indoor to outdoor ratio of fungi concentration at Golestan University Hospital in Ahvaz, Iran. Environ Pollut. 2017; 6:62-9.

[23] Park D-U, Yeom J-K, Lee WJ, Lee K-M. Assessment of the levels of airborne bacteria, gram-negative bacteria, and fungi in hospital lobbies. Int J Environ Res Public Health. 2013; 10:541-55.

[24] Cabo Verde S, Almeida SM, Matos J, Guerreiro D, Meneses M, Faria T, et al. Microbiological assessment of indoor air quality at different hospital sites. Res Microbiol. 2015; 166:557-63.

[25] Jiamjarasrangsi W, Bualert S, Chongthaleong A, Chaindamporn A, Udomsantisuk N, Euasamarnjit W. Inadequate ventilation for nosocomial tuberculosis prevention in public hospitals in Central Thailand. Int J Tuberc Lung Dis. 2009; 13:454-9. 